\title{
A Study on Users' Adoption of Electronic Payment System in India.
}

\author{
Ghana Shyam Kafley ${ }^{1}$ and Dr. M. Chandrasekaran $*^{2}$ \\ ${ }^{1}$ Research Scholar, PG and Research Department of Commerce, Nadar Mahajana Sangam S. \\ Vellaichamy Nadar College, Madurai, India. \\ ${ }^{2}$ Assistant Professor, PG and Research Department of Commerce, Nadar Mahajana Sangam S. \\ Vellaichamy Nadar College, College, Madurai, India. \\ *Corresponding Author
}

\begin{abstract}
The traditional payment system has got its own limitation to adopt recent developments in the commercial world. The growth of Electronic payment systems is inevitable in the Indian industrial and business scenario. Digital India movement of Indian Government also focuses move towards E-Payment systems. Technology has immense contribution to the growth and development of the banking sector. There have been massive changes in the concept of banking after the digitalization of India's banking sector. Commercial banks in India are facilitating their customers to develop a convenient platform for E- Payment system. In this present study, the researcher studied the relationship between the seven factors technological factors, security, Trust, social influence, internet connectivity, Perceived ease of use, Perceived Usefulness, and Intention to use to measure the adoption of e-payment systems in Madurai district. The study results show that Trust, Perceived Usefulness, and perceived ease of use are statistically significant, indicating that this variable has a positive effect on Intention to use e-payment.
\end{abstract}

Key Words: Digital Banking, TAM, E-payment, Perceived ease of use, Perceived Usefulness and Intention to use

\section{Introduction}

Technology has always played a crucial role in our life. With the advancement in technology, human life has changed. Technology has changed the concept of banking and payment system. It can understand that the growth of electronic payment systems is evidence of change in the payment methods from cash to cheques, to credit cards and debit cards, and currently to electronic payments. E-payment system has changed the concept of payment system in India from small amounts to large amounts from businessman to common person. Now people are looking for a convenient way of making payments rather than standing in the enormous queue in banks. Banking technology has changed a lot over the last decade. Users are finding it more comfortable in new technology than the traditional one.

In India, after the demonetization, there has been a massive increase in e-payment, and people are forced to learn digital payment (Kumar \& Chaubey 2017). People face several challenges, especially those living in rural areas, to adapt to new technology. People living in rural areas have a fear of losing money while making online payments. Still, people believe in cash transactions, and a large part of the population is concerned about security and privacy issues (Hasan et al., 2020). However, nowadays, it has been somehow changed by the Government and Reserve Bank of India through continuous efforts to make people aware of digital transactions and encourage people to use online payments. Nowadays, people are attracted to e-payment with various offers like cashback or a certain percent of discount. There will be a massive adoption of online banking, with the passage of time growing awareness and education (Safeena et al., 2012). 


\section{Literature Review and Hypothesis}

2.1 Technology Acceptance Mode (TAM): TAM developed by (Davis 1989) is one of the most widely used research model for estimating use and acceptance of information systems and technology by the individuals' user. TMA is based on the two beliefs, i.e., perceived usefulness and perceived ease of use are associated with the individuals' behavioral Intention to use informational technology. Both the factor significantly influences the users to use information technology. Using the TAM model as a base, numerous research has been conducted in electronic payment system adoption with some new factor. Table 1 summarizes the approaches and factors of various researchers in the field of e-payment adoption.

Table 1. Summary of approaches and purposes by researchers in e-payment adoption

\begin{tabular}{|c|c|c|c|}
\hline Researcher & Study & Purpose & Approach \\
\hline $\begin{array}{l}\text { Maryam } \\
\text { Barkhordari et } \\
\text { al. }\end{array}$ & $\begin{array}{l}\text { Factors Influencing Adoption of } \\
\text { E-Payment Systems: An } \\
\text { Empirical Study on Iranian } \\
\text { Customers }\end{array}$ & $\begin{array}{l}\text { Customers' perception of security } \\
\text { and Trust and an experimental } \\
\text { investigation on important factors } \\
\text { influencing Trust in Iran's e- } \\
\text { payments systems. }\end{array}$ & $\begin{array}{l}\text { Technical \& Transaction } \\
\text { Procedures, Access to security } \\
\text { guidelines, Usability, } \\
\text { Perceived security, Perceived } \\
\text { Trust, EPS adoption }\end{array}$ \\
\hline Sanghita Roy & $\begin{array}{l}\text { Factors Affecting Customers' } \\
\text { Adoption of Electronic Payment: } \\
\text { An Empirical Analysis }\end{array}$ & $\begin{array}{l}\text { Examine the demographic factors } \\
\text { of customers and analyze their } \\
\text { influence in the adoption of } \\
\text { Electronic Payment and clearing } \\
\text { system in the Indian banking sector }\end{array}$ & $\begin{array}{l}\text { Perceived Usefulness, } \\
\text { Perceived Ease of Use, } \\
\text { Perceived Risk, and Perceived } \\
\text { Security }\end{array}$ \\
\hline $\begin{array}{l}\text { Junadi \& } \\
\text { Sfenriantob }\end{array}$ & $\begin{array}{l}\text { A Model of Factors Influencing } \\
\text { Consumer's Intention To Use E- } \\
\text { Payment System in Indonesia }\end{array}$ & $\begin{array}{l}\text { Investigate the consumer's Intention } \\
\text { to use e-payment. }\end{array}$ & $\begin{array}{l}\text { Effort Expectancy, Perceived } \\
\text { Security, Culture, } \\
\text { Performance Expectancy, } \\
\text { Social } \\
\text { Influence, Intention to Use } \\
\text { Electronic Payment System }\end{array}$ \\
\hline $\begin{array}{l}\text { Hsueh-Ying } \\
\text { Wu et al., }\end{array}$ & $\begin{array}{l}\text { A Study of Bank Customers' } \\
\text { Perceived Usefulness Of } \\
\text { Adopting Online Banking }\end{array}$ & $\begin{array}{l}\text { Analyzed the relationship between } \\
\text { customers' perceived usefulness of } \\
\text { online banking and online } \\
\text { banking's relative advantages in } \\
\text { Taiwan. }\end{array}$ & $\begin{array}{l}\text { Relative Advantages, Web- } \\
\text { site Quality, Knowledge \& } \\
\text { Support, Information Quality } \\
\text { and Trust }\end{array}$ \\
\hline
\end{tabular}

In the present study, the original construct perceived usefulness and perceived ease of use, along with other variables such as Trust, Security, Technological factors, Social Influence, Internet Connectivity, Perceived Usefulness, Perceived Ease of Use and Intention to Use were adopted for test. Following is a brief review of previous studies on these constructs.

2.2 Technological Factor: Technological factor in e-payment refers to how users are able to use the e-payment services without having technological barriers. In India, most of the people living in rural areas are lacking in technological skills, which is a major obstacle in the adoption of e-payment (Kafley 2019). People feel that if a technology is too difficult to use, they are less willing to adopt and use it, even if they believe it is useful (Sahu \& Singh 2017). Form the above study it is clear that technological factor plays a crucial role in the adoption of e-payment system. Based on the above study, we proposed the following hypothesis.

Hypothesis 1: Technological factor in e-payment system is positively associated with the Intention to use epayment.

2.3 Security: Security refers to the confidentiality of information shared by the users' personal information, account details, data integrity, and authentication of all the participants. Electronic payment systems need to have strong security if it is not secured will not be trusted by its clients (Masihuddin et al. 2017). Security is usually associated with an organization that provides users with a security level, and risk is usually associated with consumer trust in adopting new technology (Lai 2017). From the above previous studies, it is clear that security plays a vital role in adopting e-payment system. Based on the above study, we propose the below hypothesis. 
Hypothesis 2: Security in e-payment system is positively associated with the Intention to use e-payment.

2.4 Trust: Trust in electronic payment systems refers to the consumer's confidence that e-payment transactions will be conducted according to their expectations. The adoption of e-payment must consider Trust and risk as essential determinants of adoption behavior (Tsiakis and Sthephanides 2005). Transaction on Trust and security as significant determinants of consumer use of the electronic payment system (Kim et al. 2010). Without Trust, users will not use e-payment. Based on the above study, Trust is another essential factor in the adoption of the e-payment system. We proposed the below hypothesis.

Hypothesis 3: Trust in the e-payment system is positively associated with the Intention to use e-payment.

2.5 Social Influence: Social influence in this study relates to social forces on adopting technology or innovation (Lu et al. 2005). The social Influence effect will be either positive or negative depending on whether they consider the advantages of using e-payment or the adverse experience (Hidayanto et al., 2015). Social influence play a vital role in the adoption of any new technology in society. From the above study, we proposed the below hypothesis.

Hypothesis 4: Social Influence in e-payment system is positively associated with the Intention to use epayment.

2.6 Internet Connectivity: Internet plays a vital role in the e-payment system. Without internet it is impossible to do e-payment. Poor internet service are major users concerns in the adoption of digital payment in India (Chawla \& Joshi 2019). In India, some of the users' major issued are internet connectivity, lack of Trust in online services, and threat of online theft (Sahu \& Singh 2017). From the above study, it is clear that internet connectivity is an essential factor for adopting e-payment system. Based on the previous study, we proposed the following hypothesis.

Hypothesis 5: Internet Connectivity in e-payment system is positively associated with the Intention to use epayment.

2.7 Perceived Ease of Use: Perceived Ease of Use as "the degree to which a person believes that using a technology will be free from effort" (Davis 1989). Ease of use has been associated with consumers' perception toward e-payment and is highly significant (Teoh et al., 2013). The e-payment systems are convenient and easy to use and they exert higher levels of Intention to use e-payment systems in the future among the students in different universities in the United Arab of Emirates (Salloum \& Al-Emran 2018). From the above studies, it is clear that ease of use in the e-payment system plays a vital role in adopting epayment. Based on the above study, we propose the following hypothesis.

Hypothesis 6: Perceived Ease of Use in e-payment system is positively associated with the Intention to use epayment.

2.8 Perceived Usefulness: Perceived Usefulness refers to "the extent to which a person believes that using a particular technology will enhance her/his job performance" (Davis 1989). In empirical research, they have found that perceived ease of use and perceived usefulness significantly impact consumer adaptation intentions (Chen \& Barnes 2007). Perceived usefulness and perceived ease of use directly relate to the Intention to adopt online banking (Guriting \& Ndubisi 2006). From the above study, it is clear that Efficiency in the e-payment system has an essential role in adopting the e-payment system. Based on the above study, we proposed the below hypothesis.

Hypothesis 7: Perceived Usefulness in e-payment system is positively associated with the Intention to use epayment.

2.9 Intention to use e-payment: Intention to use in e-payment refers to how users accept and continuously use the e-payment and how they influence others to use the e-payment. There is a significant relationship between security and Intention to use e-payment system (Lia 2017). Customers' willingness to use a new technology or mobile device may be affected by security and privacy concerns (Luarn \& Lin, 2005). From the above studies, it is clear that the Intention to use e-payment plays a vital role in adopting e-payment.

\section{Research Methodology}

Due to corona pandemic face to face interaction with the respondent was not possible so that the convenience sampling method is used to collect primary data since the electronic payment system population is unknown, probability sampling may not be an appropriate one. The sample data were collected from January 2021 to February 2021 in Madurai District. The sample size for this study has been decided up to 250. There are 
255 questionnaires have sent through mail to the respondents in Madurai District out of these two filled questionnaires have not been included for analysis since contained missing information and the three mailed questionnaires were not turned back.

\section{Conceptual Framework of the Study}

The study have been conducted with the predetermined framework which contains the factors influencing Intention to use of electronic payment system. One endogenous variable which is called Intention to Use and seven exogenous variable which constituted factors influencing to used electronic payment system.

\section{Figure 1 Conceptual Framework of the Study}

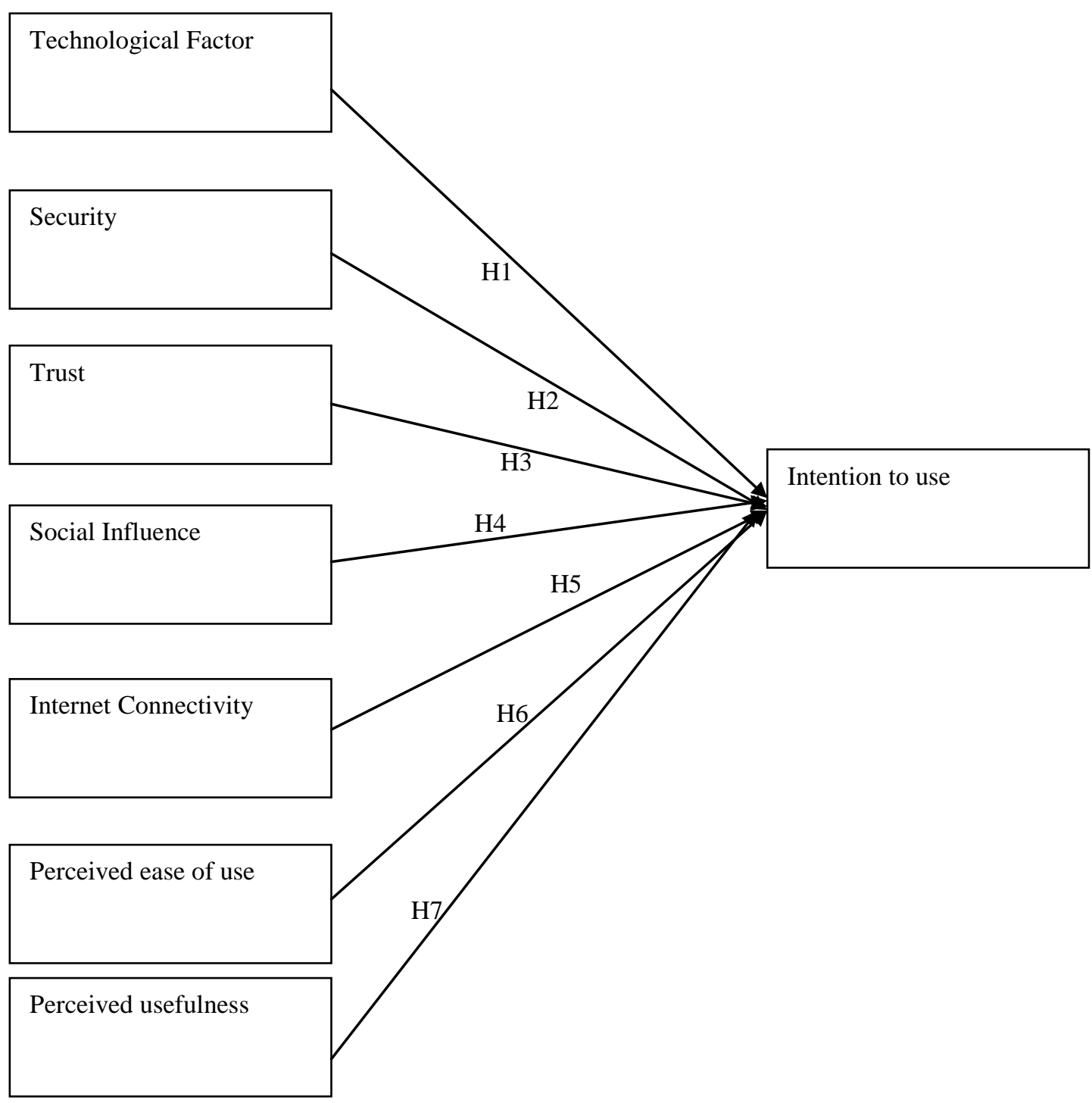

There are seven factors have been considered to measure the Intention to use electronic payment system such as technological factors, security, Trust, social influence, internet connectivity, Perceived ease of use and Perceived Usefulness. Each factor has five statements for the better measurement of the respondent's level of opinion with regards to adoption. Likert's five point scale is used to measure the respondent's opinion ranging from 5 (Strongly agree) to 1 (Strongly Disagree). Pilot study was conducted with the sample size of 50 to check the reliability and validity of the data collecting scales. Some respondents were need clarification in some questions subsequent changes have been made to improve the questionnaire accuracy. 


\section{Demographic Profile of the Respondents}

Respondents are classified on the basis of their demographic profile. This basic classification is essential to understand the distribution of sample size among wide range of respondents. Gender, age, educational qualification, and occupation are the major factors motivating the respondents to use electronic payment systems. So the respondents are classified based on the important demographic profile.

Table 2. Demographic Profile of Respondent

\begin{tabular}{cccc}
\hline Demographic & Items & $\begin{array}{c}\text { Number of } \\
\text { Respondent }\end{array}$ & Percentage \\
\hline Gender & Male & 136 & 54.4 \\
\hline Total & Female & 114 & 45.6 \\
\hline Age & & $\mathbf{2 5 0}$ & $\mathbf{1 0 0 . 0}$ \\
\hline & Up to 30 & 65 & 26.0 \\
\hline & $31-40$ & 81 & 32.4 \\
\hline Total & $41-50$ & 62 & 24.8 \\
\hline Qualification & Above 51 & 42 & 16.8 \\
\hline & & $\mathbf{2 5 0}$ & $\mathbf{1 0 0 . 0}$ \\
\hline & Up to Higher Secondary & 37 & 14.8 \\
\hline Total & Graduation/Diploma & 81 & 32.4 \\
\hline Occupation & Post Graduation/ Professional & 106 & 42.4 \\
\hline & No proper Education & 26 & 10.4 \\
\hline & & $\mathbf{2 5 0}$ & $\mathbf{1 0 0 . 0}$ \\
\hline & Government sector employee & 57 & 22.8 \\
\hline & Private sector Employee & 52 & 20.8 \\
\hline Total & Student & 44 & 17.6 \\
\hline Dacation & Business & 59 & 23.6 \\
\hline & Agricultural & 38 & 15.2 \\
\hline & & $\mathbf{2 5 0}$ & $\mathbf{1 0 0 . 0}$ \\
\hline
\end{tabular}

Source: Primary Data

Table 2 shows the demographic profile of the respondents. The majority of the respondents are male, 54.4 percent, and Female, 45.6 percent. The majority of the respondent is in the age group between 31-40 years, 32.4 percent, 26 percent are up to 30 years, 24.8 percent are between $41-50$ years old, and 16.8 are above 51 years old. 42.4 percent of the respondents have education level up to Post Graduation/ Professional, 32.4 percent have completed Graduation/Diploma, 14.8 percent have education qualification Up to Higher Secondary, and 10.4 do not have a proper education. Most of the respondent is from the business community 23.6 percent, followed by Government Sector employee 22.8 percent, private sector employees 20.8 percent, student 17.6 percent and agricultural 15.2 percent.

\section{Result and Discussion}

The result of multiple regression analysis and the model summary indicated that the overall model of the seven independent variables is significantly related to the users' Intention to use e-payment. In this study, the dependent variable is Intention to Use, independent variables are Technological Factor, Security, Trust, Social Influence, Internet Connectivity, Perceived Usefulness, and Perceived Ease of Use and analysis are discussed as follows:

Multiple $\mathrm{R}$ value $=0.858$

$\mathrm{R}^{2}=0.862$

F Value: $(7,240)=215.06$

P Value : $<0.001 * *$

The multiple correlation coefficient is 0.858 measures the degree of relationship between the actual values and the predicted values of the Intention to use e-payment. Because the predicted values are obtained as a linear combination of technological factor, security, Trust, social influence, internet connectivity, perceived usefulness, and perceived ease of use the coefficient value of 0.858 indicates that the relationship between Intention to use and the seven independent variables is quite strong and positive. The value of $R$ square is 0.862 
simply means that about 86.2 percent the predictors accounts the variation in Intention to use e-payment and $\mathrm{R}$ square value is significant at $1 \%$ level.

Table 3 Regression Results

\begin{tabular}{cccccc}
\hline & Un standardized Coefficients & $\begin{array}{c}\text { Standardized } \\
\text { Coefficients }\end{array}$ & $\mathrm{t}$ & Sig. \\
\hline & $\mathrm{B}$ & Std. Error & $\beta$ & & \\
\hline $\begin{array}{c}\text { (Constant) } \\
\text { Technological } \\
\text { Factor }\end{array}$ & 0.785 & 0.492 & & 1.597 & 0.112 \\
\hline Security & 0.116 & 0.067 & 0.116 & 1.735 & 0.084 \\
\hline Trust & 0.185 & 0.062 & 0.116 & 1.895 & 0.059 \\
\hline Social Influence & 0.019 & 0.060 & 0.189 & 2.973 & $0.003^{*}$ \\
\hline $\begin{array}{c}\text { Internet } \\
\text { Connectivity }\end{array}$ & 0.116 & 0.059 & 0.117 & 1.959 & 0.051 \\
\hline $\begin{array}{c}\text { Perceived } \\
\text { Usefulness }\end{array}$ & 0.222 & 0.067 & 0.236 & 3.336 & $0.001^{*}$ \\
\hline $\begin{array}{c}\text { Perceived ease of } \\
\text { use }\end{array}$ & 0.188 & 0.061 & 0.188 & 3.084 & $0.002^{*}$ \\
\hline Source Prin
\end{tabular}

Source: Primary Data

* Denotes $1 \%$ level of significance

Table 3 shows the regression results. The general liner equation for these studies is as follows:

$$
Y=0.116 X_{1}+0.118 X_{2}+0.185 X_{3}+0.019 X_{4}+0.116 X_{5}+0.222 X_{6}+0.188 X_{7}+0.785
$$

Here, $\mathrm{Y}$ is a dependent variable called Intention to use, $\mathrm{X}_{1}-$ Technological Factor, $\mathrm{X}_{2}-$ Security, $\mathrm{X}_{3}-\mathrm{Trust}, \mathrm{X}_{4}$ - Social Influence, $\mathrm{X}_{5}$ - Internet Connectivity, $\mathrm{X}_{6}-$ Perceived Usefulness and $\mathrm{X}_{7}$ - Perceived ease of use.

$\mathrm{P}$ - value of Technological factor is 0.084 which is more than 0.05 the null hypothesis is accepted at 5 percent level of significance. Hence, technological factor in e-payment system is not positively associated with the Intention to use e-payment.

$\mathrm{P}-$ Value of security is 0.059 which is more than 0.05 the null hypothesis is accepted at 5 percent level of significance. Hence, Security in e-payment system is not positively associated with the Intention to use epayment.

$\mathrm{P}-$ Value of Trust is 0.003 which is less than 0.01 the null hypothesis is accepted at 1 percent level of significance. Hence, Trust in e-payment system is positively associated with the Intention to use e-payment.

$\mathrm{P}-$ Value of Social Influence is 0.757 which is more than 0.05 the null hypothesis is accepted at 5 percent level of significance. Hence, Social Influence in e-payment system is not positively associated with the Intention to use e-paymen.

$\mathrm{P}$ - Value of Internet Connectivity is 0.051 which is more than 0.05 the null hypothesis is accepted at 5 percent level of significance. Hence, Internet Connectivity in e-payment system is not positively associated with the Intention to use e-payment.

$\mathrm{P}-$ Value of Perceived Usefulness is 0.003 which is less than 0.01 the null hypothesis is rejected at 1 percent level of significance. Hence, Perceived Usefulness in e-payment system is positively associated with the Intention to use e-payment.

$\mathrm{P}$ - Value of Perceived ease of use is 0.002 which is less than 0.01 the null hypothesis is rejected at 1 percent level of significance. Hence, Perceived ease of use in e-payment system is positively associated with the Intention to use e-payment.

\section{Conclusion}

The result of regression analysis shows that Trust, Perceived Usefulness, and Perceived ease of use positively influence Intention to use e-payment system. Trust is most important when it comes to any virtual financial transaction. Similarly, Perceived Usefulness and Perceived Ease of use are also crucial if it is useful and easy to use, users will automatically adopt or use that technology to save their time, energy, and efforts. The regression analysis concluded that all seven factors are combinedly increasing an intention to use e-payment system. Technological factor, Security, Trust, Social influence, Internet connectivity, Perceived usefulness, and 
Perceived ease of use influencing more on Intention to use e-payment system rather than other factors. Increasing Intention to use electronic payment system should build with the highest combination of trust towards electronic payment system, wide ranges of payment facilities coverage, and user-friendly interface of the electronic system.

\section{Limitation of the study}

The present study also has its own limitations. The study results have been generalized based on study conducted only with reference to Madurai District. The study is conducted only with limited sample size of only 250 sample size and primary data collected only during January 2021 to February 2021 . There are only seven factors have been taken into account to measure the Intention to use of electronic payment system.

\section{Reference}

9. Barkhordari, M., Nourollah, Z., Mashayekhi, H., Mashayekhi, Y., \& Ahangar, M. S. (2017).Factors influencing adoption of e-payment systems: an empirical study on Iranian customers. Information systems and e-business management, 15(1), 89-116.

10. Chawla, D., \& Joshi, H. (2019). Consumer attitude and Intention to adopt mobile wallet in India-An empirical study. International Journal of Bank Marketing.

11. Chen, Y. H., \& Barnes, S. (2007). Initial Trust and online buyer behaviour. Industrial management \& data systems.

12. Davis, F. D. (1989). Perceived usefulness, perceived ease of use, and user acceptance of information technology. MIS quarterly, 319-340.

13. Guriting, P., \& Ndubisi, N. O. (2006). Borneo online banking: evaluating customer perceptions and behavioural Intention. Management research news.

14. Hasan, A., AtifAman, M., \& Ali, M. A. (2020). Cashless Economy in India: Challenges Ahead. Journal of Commerce, 8(1), 21-30.

15. Hidayanto, A. N., Hidayat, L. S., Sandhyaduhita, P. I., \& Handayani, P. W. (2015). Examining the relationship of payment system characteristics and behavioural Intention in e-payment adoption: a case of Indonesia. International Journal of Business Information Systems, 19(1), 58-86.

16. Junadia ${ }^{\text {a }}$ S. (2015). A model of factors influencing consumer's Intention to use e-payment system in Indonesia. Procedia Computer Science, 59, 214-220.

17. Kafley, G. S. (2019). E-payment system in rural India: Issues and Challenges.

18. Kumar, P., \& Chaubey, D. S. (2017). Demonetization and its impact on adoption of digital payment: Opportunities, issues and challenges. Abhinav National Monthly Refereed Journal of Research in Commerce \& Management, 6(6), 15.

19. Kim, C., Tao, W., Shin, N., \& Kim, K. S. (2010). An empirical study of customers' perceptions of security and Trust in e-payment systems. Electronic commerce research and applications, 9(1), 84-95.

20. Lai, P. C. (2017). Security as an extension to TAM model: Consumers' Intention to use a single platform E-Payment. Asia-Pacific Journal of Management Research and Innovation, 13(3-4), 110-119.

21. Lu, J., Yao, J. E., \& Yu, C. S. (2005). Personal innovativeness, social influences and adoption of wireless Internet services via mobile technology. The Journal of Strategic Information Systems, 14(3), 245-268. 
22. Luarn, P. dan Lin, H. 2005. Toward an understanding of the behavioral Intention to use mobile banking. Computer Human Behavior, 21, 873, 891.

23. Masihuddin, M., Khan, B. U. I., Mattoo, M. M. U. I., \& Olanrewaju, R. F. (2017). A survey on epayment systems: elements, adoption, architecture, challenges and security concepts. Indian Journal of Science and Technology, 10(20), 1-19.

24. Roy, S., \& Sinha, I. (2017). Factors affecting Customers' adoption of Electronic Payment: an Empirical Analysis. Journal of Business and Management, 19(12), 76-90.

25. Sahu, G. P., \& Singh, N. K. (2017, November). Paradigm shift of Indian cash-based economy to cashless economy: a study on Allahabad City. In Conference on e-Business, e-Services and e-Society (pp. 453-461). Springer, Cham.

26. Safeena, R., Date, H., Kammani, A., \& Hundewale, N. (2012). Technology adoption and Indian consumers: study on mobile banking. International Journal of Computer Theory and Engineering, 4(6), 1020 .

27. Tsiakis, T., \& Sthephanides, G. (2005). The concept of security and Trust in electronic payments. Computers \& Security, 24(1), 10-15.

28. Salloum, S. A., \& Al-Emran, M. (2018). Factors affecting the adoption of E-payment systems by university students: Extending the TAM with Trust. International Journal of Electronic Business, 14(4), 371-390.

29. Teoh, W. M. Y., Chong, S. C., Lin, B., \& Chua, J. W. (2013). Factors affecting consumers' perception of electronic payment: an empirical analysis. Internet Research.

30. Wu, H. Y., Lin, C. C., Li, O., \& Lin, H. H. (2010). A study of bank customers' perceived usefulness of adopting online banking. Global journal of business research, 4(3), 101-108. 